\title{
Characterization of norepinephrine-evoked inward currents in interstitial cells isolated from the rabbit urethra
}

\author{
G. P. Sergeant, K. D. Thornbury, N. G. McHale and M. A. Hollywood \\ Am J Physiol Cell Physiol 283:C885-C894, 2002. First published 15 May 2002; \\ doi:10.1152/ajpcell.00085.2002
}

You might find this additional info useful...

This article cites 34 articles, 17 of which can be accessed free at:

http://ajpcell.physiology.org/content/283/3/C885.full.html\#ref-list-1

This article has been cited by 11 other HighWire hosted articles, the first 5 are:

Presence of the $\mathrm{Ca}^{2+}$-activated chloride channel anoctamin 1 in the urethra and its role in excitatory neurotransmission

Maria Sancho, Angeles García-Pascual and Domingo Triguero

Am J Physiol Renal Physiol, February , 2012; 302 (3): F390-F400.

[Abstract] [Full Text] [PDF]

Direct coupling through gap junctions is not involved in urethral neurotransmission

Maria Sancho, Domingo Triguero and Angeles Garcia-Pascual

Am J Physiol Renal Physiol, April , 2011; 300 (4): F864-F872.

[Abstract] [Full Text] [PDF]

Presence of cyclic nucleotide-gated channels in the rat urethra and their involvement in nerve-mediated nitrergic relaxation

Domingo Triguero, María Sancho, Marta García-Flores and Ángeles García-Pascual

Am J Physiol Renal Physiol, November , 2009; 297 (5): F1353-F1360.

[Abstract] [Full Text] [PDF]

Interstitial cells of Cajal in the urethra are cGMP-mediated targets of nitrergic neurotransmission

Ángeles García-Pascual, María Sancho, Gonzalo Costa and Domingo Triguero

Am J Physiol Renal Physiol, October 1, 2008; 295 (4): F971-F983.

[Abstract] [Full Text] [PDF]

Role of mitochondria in modulation of spontaneous $\mathrm{Ca}^{2+}$ waves in freshly dispersed interstitial cells of Cajal from the rabbit urethra

Gerard P. Sergeant, Eamonn Bradley, Keith D. Thornbury, Noel G. McHale and Mark A.

Hollywood

J Physiol, October 1, 2008; 586 (19): 4631-4642.

[Abstract] [Full Text] [PDF]

Updated information and services including high resolution figures, can be found at:

http://ajpcell.physiology.org/content/283/3/C885.full.html

Additional material and information about AJP - Cell Physiology can be found at:

http://www.the-aps.org/publications/ajpcell

This infomation is current as of March 8, 2012.

AJP - Cell Physiology is dedicated to innovative approaches to the study of cell and molecular physiology. It is published 12 times a year (monthly) by the American Physiological Society, 9650 Rockville Pike, Bethesda MD 20814-3991. Copyright () 2002 by the

American Physiological Society. ISSN: 0363-6143, ESSN: 1522-1563. Visit our website at http://www.the-aps.org/. 


\title{
Characterization of norepinephrine-evoked inward currents in interstitial cells isolated from the rabbit urethra
}

\author{
G. P. SERGEANT, K. D. THORNBURY, N. G. McHALE, AND M. A. HOLLYWOOD \\ Smooth Muscle Group, Department of Physiology, The Queen's \\ University of Belfast, BT9 7BL Belfast, United Kingdom
}

Received 25 February 2002; accepted in final form 3 May 2002

\begin{abstract}
Sergeant, G. P., K. D. Thornbury, N. G. McHale, and M. A. Hollywood. Characterization of norepinephrineevoked inward currents in interstitial cells isolated from the rabbit urethra. Am $J$ Physiol Cell Physiol 283: C885-C894, 2002. First published May 16, 2002; 10.1152/ ajpcell.00085.2002.-Freshly dispersed interstitial cells from the rabbit urethra were studied by using the perforatedpatch technique. When cells were voltage clamped at -60 $\mathrm{mV}$ and exposed to $10 \mu \mathrm{M}$ norepinephrine (NE) at 80-s intervals, either large single inward currents or a series of oscillatory inward currents of diminishing amplitude were evoked. These currents were blocked by either phentolamine $(1 \mu \mathrm{M})$ or prazosin $(1 \mu \mathrm{M})$, suggesting that the effects of NE were mediated via $\alpha_{1}$-adrenoceptors. NE-evoked currents were depressed by the blockers of $\mathrm{Ca}^{2+}$-activated $\mathrm{Cl}^{-}$currents, niflumic acid (10 $\mu \mathrm{M})$, and 9-anthracenecarboxylic acid (9-AC, $1 \mathrm{mM})$. The reversal potential of the above currents changed in a predictable manner when the $\mathrm{Cl}^{-}$equilibrium potential was altered, again suggesting that they were due to activation of a $\mathrm{Cl}^{-}$conductance. NE-evoked currents were decreased by $10 \mu \mathrm{M}$ cyclopiazonic acid, suggesting that they were dependent on store-released $\mathrm{Ca}^{2+}$. Inhibition of $\mathrm{NE}$ evoked currents by the phospholipase $\mathrm{C}$ inhibitor 2-nitro-4carboxyphenyl- $N, N$-diphenylcarbamate $(100 \mu \mathrm{M})$ suggested that NE releases $\mathrm{Ca}^{2+}$ via an inositol 1,4,5-trisphosphate $\left(\mathrm{IP}_{3}\right)$-dependent mechanism. These results support the idea that stimulation of $\alpha_{1}$-adrenoceptors releases $\mathrm{Ca}^{2+}$ from an $\mathrm{IP}_{3}$-sensitive store, which in turn activates $\mathrm{Ca}^{2+}$-activated $\mathrm{Cl}^{-}$current in freshly dispersed interstitial cells of the rabbit urethra. This elevates slow wave frequency in these cells and may underlie the mechanism responsible for increased urethral tone during nerve stimulation.
\end{abstract}

chloride; pacemaker cell; neurotransmission

THE URETHRA IS THOUGHT to play an important role in maintaining urinary continence by generating sufficient tone to prevent leakage of urine from the bladder. Although this tone is largely myogenic in nature, it can also be augmented by adrenergic nerves acting on postjunctional $\alpha_{1}$-receptors $(6,7)$. Recent evidence suggests that $\mathrm{Ca}^{2+}$-activated $\mathrm{Cl}^{-}$channels may play an important role in the generation of spontaneous myogenic tone in the urethra $(10,12,27,28)$. However, the precise mechanisms mediating $\alpha_{1}$ responses in the

Address for reprint requests and other correspondence: M. Hollywood, Smooth Muscle Group, Dept. of Physiology, The Queen's Univ. of Belfast, 97 Lisburn Road, BT9 7BL Belfast, United Kingdom (E-mail: m.hollywood@qub.ac.uk; website: www.smoothmusclegroup.org). urethra remain unknown, although a number of sharp microelectrode recordings made from the urethras of guinea pigs and rabbits demonstrated that exogenously applied norepinephrine (NE) could increase the frequency of slow waves $[9,12]$.

Recent studies in our laboratory $(27,28)$ demonstrated that a small population of freshly dispersed cells from the rabbit urethra shared similar characteristics with interstitial cells of Cajal (ICC) believed to be the pacemaker cells in the gastrointestinal (GI) tract $(17,19,25,26,31,32)$. These urethral interstitial cells were vimentin positive, noncontractile, and spontaneously active and were therefore postulated to be "pacemaker" cells in the rabbit urethra. A parallel could therefore be made between interstitial cells in the urethra and ICC in the GI tract. Because ICC act not only as pacemakers but also as mediators of neurotransmission $(8,26,34,35)$, it was of interest to investigate whether interstitial cells could play a similar role in the urethra. In support of this hypothesis is the observation that exogenously applied NE increased the frequency of spontaneous transient depolarizations (STDs) recorded from isolated urethral interstitial cells (27), demonstrating that NE could directly influence isolated urethral interstitial (pacemaker) cells. This novel finding may prove to have important implications with regard to mechanisms controlling urethral tone. In this study we have characterized the mechanisms underlying the effect of exogenous $\mathrm{NE}$ on isolated interstitial cells and investigated whether these cells contribute to neurogenic responses in the rabbit urethra.

\section{MATERIALS AND METHODS}

The bladder and urethra were removed from both male and female rabbits immediately after they had been killed by lethal injection of pentobarbitone. The most proximal $1 \mathrm{~cm}$ of the urethra was removed and placed in Krebs solution, and from this, strips were dissected for cell dispersal or for tension recording.

Cell dispersal. Strips of proximal urethra $0.5 \mathrm{~cm}$ in width were cut into $1-\mathrm{mm}^{3}$ pieces and stored in Hanks' $\mathrm{Ca}^{2+}$-free solution for 30 min before being incubated in dispersal me-

The costs of publication of this article were defrayed in part by the payment of page charges. The article must therefore be hereby marked "advertisement" in accordance with 18 U.S.C. Section 1734 solely to indicate this fact. 
A

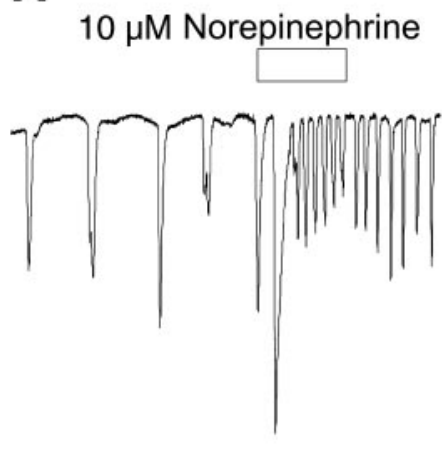

B

\section{$10 \mu \mathrm{M}$ Norepinephrine}

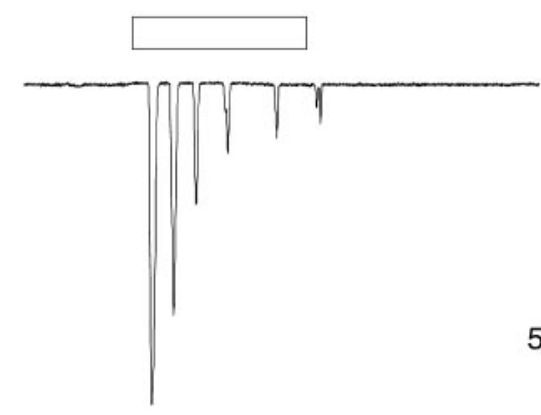

C

\section{$10 \mu \mathrm{M}$ Norepinephrine}

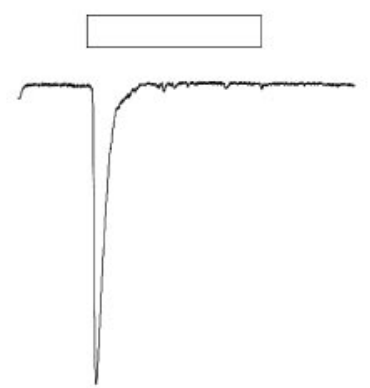

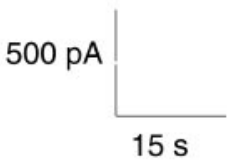

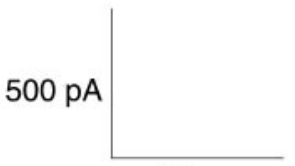

$10 \mathrm{~s}$

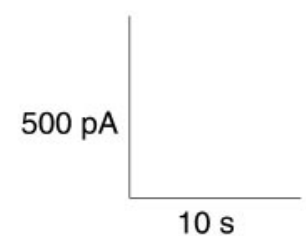

Fig. 1. Effect of norepinephrine (NE) on isolated interstitial cells. In voltage clamp, NE $(10 \mu \mathrm{M})$ could either increase the frequency of spontaneous transient inward currents (STICs; $A$ ), evoke a series of inward currents of diminishing amplitude $(B)$, or evoke a large single inward current $(C)$.

dium containing [per $5 \mathrm{ml}$ of $\mathrm{Ca}^{2+}$-free Hanks' solution (see Solutions): $15 \mathrm{mg}$ collagenase (Sigma type 1A), $0.5 \mathrm{mg}$ protease (Sigma type XXIV), $5 \mathrm{mg}$ bovine serum albumin (Sigma), and $15 \mathrm{mg}$ trypsin inhibitor (Sigma)] for 10-15 min at $37^{\circ} \mathrm{C}$. Tissue was then transferred to $\mathrm{Ca}^{2+}$-free Hanks' solution and stirred for an additional 15-30 min to release single smooth muscle cells and interstitial cells. These cells were plated in petri dishes containing $100 \mu \mathrm{M} \mathrm{Ca}^{2+}$ Hanks' solution and stored at $4^{\circ} \mathrm{C}$ for use within $8 \mathrm{~h}$.

Solutions. The compositions of the solutions used were as follows (in $\mathrm{mM}$ ): 1) Hanks' solution, $129.8 \mathrm{Na}^{+}, 5.8 \mathrm{~K}^{+}, 135$ $\mathrm{Cl}^{-}, 4.17 \mathrm{HCO}_{3}^{-}, 0.34 \mathrm{HPO}_{4}^{2-}, 0.44 \mathrm{H}_{2} \mathrm{PO}_{4}^{-}, 1.8 \mathrm{Ca}^{2+}, 0.9$ $\mathrm{Mg}^{2+}, 0.4 \mathrm{SO}_{4}^{2-}, 10$ glucose, 2.9 sucrose, and 10 HEPES, $\mathrm{pH}$ adjusted to 7.4 with $\mathrm{NaOH}$; 2) $49 \mathrm{mM} \mathrm{Cl}^{-}$Hanks' solution, $129.8 \mathrm{Na}^{+}, 5.8 \mathrm{~K}^{+}, 86$ glutamate, $49 \mathrm{Cl}^{-}$, $4.17 \mathrm{HCO}_{3}^{-}, 0.34$

$\mathrm{HPO}_{4}^{2-}, 0.44 \mathrm{H}_{2} \mathrm{PO}_{4}^{-}, 1.8 \mathrm{Ca}^{2+}, 0.9 \mathrm{Mg}^{2+}, 0.4 \mathrm{SO}_{4}^{2-}, 10$ dextrose, 2.9 sucrose, and 10 HEPES, $\mathrm{pH}$ adjusted to 7.4 with $\mathrm{NaOH}$; 3) $\mathrm{Cs}^{+}$perforated-patch pipette solution, $133 \mathrm{Cs}^{+}$, $135 \mathrm{Cl}^{-}, 1.0 \mathrm{Mg}^{2+}, 0.5 \mathrm{EGTA}$, and 10 HEPES, $\mathrm{pH}$ adjusted to 7.2 with $\mathrm{CsOH}$; and 4) Krebs solution $146.2 \mathrm{Na}^{+}, 5.9 \mathrm{~K}^{+}$, $133.3 \mathrm{Cl}^{-}, 25 \mathrm{HCO}_{3}^{-}, 1.2 \mathrm{H}_{2} \mathrm{PO}_{4}^{-}, 2.5 \mathrm{Ca}^{2+}, 1.2 \mathrm{Mg}^{2+}$, and 11 glucose, $\mathrm{pH}$ maintained at 7.4 by bubbling with $95 \%$ $\mathrm{O}_{2}-5 \% \mathrm{CO}_{2}$.

Perforated-patch recordings from single cells. Currents were recorded by using the perforated-patch configuration of the whole cell patch-clamp technique $(15,24)$. This circumvented the problem of current rundown encountered using the conventional whole cell configuration. The cell membrane was perforated by using the antibiotic amphotericin B (600 $\mu \mathrm{g} / \mathrm{ml}$ ). Patch pipettes were initially front-filled by being dipped into pipette solution and were then backfilled with the amphotericin B-containing solution. Pipettes were pulled from borosilicate glass capillary tubing (1.5-mm outer diameter, 1.17-mm inner diameter; Clark Medical Instruments) to a tip of diameter $\sim 1-1.5 \mu \mathrm{m}$ and resistance of $2-4 \mathrm{M} \Omega$.

Series resistance and capacitative currents were usually uncompensated for in this study. Voltage-clamp commands were delivered via an Axopatch one-dimensional patch-clamp amplifier (Axon Instruments), and membrane currents were recorded by a 12-bit analog-to-digital/digital-to-analog converter (Axodata 1200 or Labmaster-Scientific Solutions) interfaced to an AT-type computer running pCLAMP software. During experiments, the dish containing the cells was continuously perfused with Hanks' solution (see Solutions) at $37 \pm 1^{\circ} \mathrm{C}$. Additionally, the cell under study was continuously superfused by means of a custom-built close delivery system with a pipette of tip diameter $200 \mu \mathrm{m}$ placed $\sim 300 \mu \mathrm{m}$ from the cell. The Hanks' solution in the close delivery system could be switched to a drug-containing solution with a deadspace time of $<5 \mathrm{~s}$. The effect of $\mathrm{NE}$ was quantified by examining the peak amplitude of the inward currents evoked by NE. Where stated, data were corrected for junction potentials of $-3 \mathrm{mV}$ in standard Hanks' solution and $+2 \mathrm{mV}$ in low-chloride Hanks'. Summary data are presented as means $\pm \mathrm{SE}$, and statistical comparisons were made on raw data by using Students' paired $t$-test, taking the $P<0.05$ level as significant.

Isolated tissue recording. Circularly orientated strips $(8 \times$ $1 \times 1 \mathrm{~mm})$ of smooth muscle were removed from rabbit urethra, placed in a water-jacketed organ bath maintained at $37^{\circ} \mathrm{C}$, and perfused with warmed Krebs solution that was bubbled with $95 \% \mathrm{O}_{2}-5 \% \mathrm{CO}_{2}$. Strips were adjusted to a tension of $2-4 \mathrm{mN}$ and allowed to equilibrate for $50 \mathrm{~min}$ before experimentation began. Contractions were measured by using Statham UC3 and Dynamometer UF1 transducers, the outputs of which were recorded on a Grass 7400 chart recorder. Transmural nerve stimulation was applied by a Grass S11 stimulator, which delivered 0.3-ms pulses of $50 \mathrm{~V}$ (nominal) at a frequency of $10 \mathrm{~Hz}$. Pulses were applied for $0.1,0.3,1,3$, and $10 \mathrm{~s}$. Stimuli were applied $\sim 1$ min after the preceding neurogenic contraction had returned to baseline levels. All experiments were carried out in the presence of atropine $(1 \mu \mathrm{M})$ and $N^{\omega}$-nitro-L-arginine $(10 \mu \mathrm{M})$ to block contributions from cholinergic and nitrergic nerves.

Drugs. The following drugs were used: amphotericin B (Sigma), 2-aminoethoxydiphenyl borate (2-APB; Sigma), 9-anthracenecarboxylic acid (9-AC; Sigma), 2-nitro-4-carboxyphenyl- $N, N$-diphenylcarbamate (NCDC; Sigma), atropine (BDH Laboratories), caffeine (Sigma), cyclopiazonic acid (CPA; Calbiochem), dimethyl sulfoxide (DMSO; Sigma), $N^{\omega}$-nitro-L-arginine (Sigma), niflumic acid (Sigma), NE 
(Levophed; Sanofi Winthrop, UK), penitrem A (Sigma), phentolamine (Ciba), and prazosin (Tocris).

Stock solutions of 9-AC (0.1 M), niflumic acid (0.01 M), penitrem $\mathrm{A}(0.1 \mathrm{mM})$, and CPA $(0.01 \mathrm{M})$ were made in DMSO. 2-APB and NCDC were made in stock solutions of ethanol $(0.1 \mathrm{M})$. Drug vehicles had no effect on the currents studied. Prazosin was dissolved in distilled water to give a $0.01 \mathrm{M}$ stock solution. All drugs were then diluted to their final concentrations in Hanks' or Krebs solution. NE and phentolamine were dissolved directly into experimental solutions to give the required concentrations.

\section{RESULTS}

Digestion of rabbit urethral smooth muscle strips yielded both interstitial cells and smooth muscle cells. Although the majority of cells were smooth muscle, interstitial cells could be easily distinguished from smooth muscle cells by using a number of criteria (27). Thus interstitial cells were highly branched, failed to contract in response to depolarizing current injection or application of $\mathrm{NE}$, possessed abundant $\mathrm{Ca}^{2+}$-activated $\mathrm{Cl}^{-}$current, and normally fired spontaneous transient inward currents. In a previous study we demonstrated that NE $(10 \mu \mathrm{M})$ enhanced the frequency of slow waves in isolated urethral interstitial cells, but the mechanisms underlying this effect were not examined (27). In this study we carried out a series of experiments to establish the mechanisms through which NE mediates its effects on these cells.

Effect of $N E$. Figure 1 shows typical examples of the effect of NE (10 $\mu \mathrm{M})$ on spontaneous activity in interstitial cells held under voltage clamp. When cells were held at $-60 \mathrm{mV}$, spontaneous transient inward currents (STICs) were apparent, and application of $10 \mu \mathrm{M}$ NE evoked a large inward current followed by a series of currents of diminishing amplitude. These results suggest that the elevation of STIC frequency underlies the increase in slow wave activity observed previously (27). The effects of NE were reproducible within the same cell if a period of $80 \mathrm{~s}$ was allowed between successive applications, presumably reflecting a combination of the time taken for the NE-sensitive store to refill and the cell to recover from desensitization. Although the effects of NE on individual interstitial cells were reproducible, variable responses to NE were elicited in different cells. In 16 of 35 cells examined, NE evoked currents similar to those shown in Fig. 1, $A$ and $B$. They consisted of a large transient inward current that was followed by a series of smaller inward currents with a mean frequency of $7 \pm 1 \mathrm{~min}^{-1}$. In the remaining 19 cells, application of NE evoked large single inward currents similar to that shown in Fig. $1 C$.

Effect of $\alpha$-adrenoceptor antagonists. Having demonstrated that NE could evoke large transient inward currents, we assessed the involvement of $\alpha$-adrenoceptors in this response by examining the effect of phentolamine and prazosin on the response to NE. Figure $2 A$ shows a typical response to NE before, during, and after application of the nonspecific $\alpha$-adrenoceptor antagonist phentolamine $(1 \mu \mathrm{M})$. Figure $2 B$ shows a summary bar chart for six experiments in which phentolamine decreased the mean peak inward current from
A
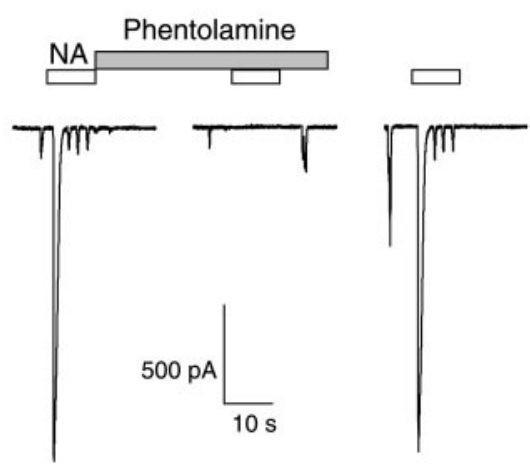

B

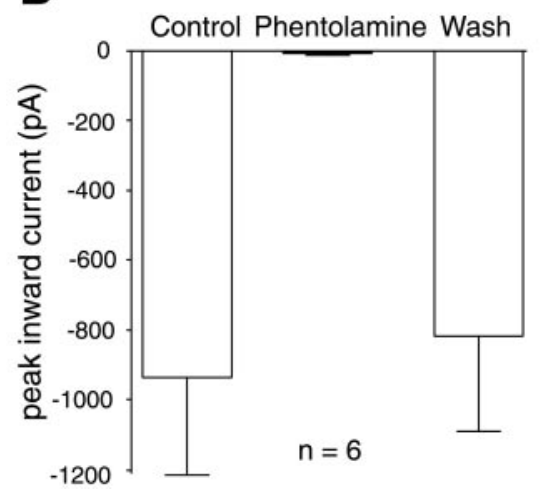

C

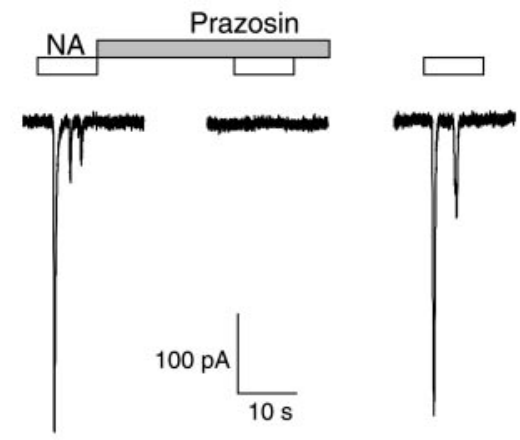

Fig. 2. Blockade of NE response by $\alpha$-adrenoceptor antagonists. Application of NE evoked a series of inward currents, which were reversibly abolished by phentolamine $(A)$ or prazosin $(C) . B$ and $D$ show summary data in which the effect of $\mathrm{NE}$ was examined before (control), during, and after (wash) application of phentolamine $(1 \mu \mathrm{M})$ or prazosin $(1 \mu \mathrm{M})$, respectively. 
$-938 \pm 277 \mathrm{pA}$ to $-2 \pm 2 \mathrm{pA}(P<0.05)$. Upon washout, application of NE evoked currents of $-816 \pm 272 \mathrm{pA}$. We next examined the effect of the $\alpha_{1}$-adrenoceptor antagonist prazosin $(1 \mu \mathrm{M})$ on the response to NE. Figure $2 C$ demonstrates that the response to NE was mediated via activation of $\alpha_{1}$-adrenoceptors because it was reversibly abolished by prazosin. In five similar experiments, NE evoked inward currents of $-618 \pm$ $278 \mathrm{pA}(n=5)$ before application of prazosin. In the presence of prazosin, $\mathrm{NE}$ failed to elicit any inward currents, but upon washout the amplitude of the NEevoked current was $-669 \pm 354 \mathrm{pA}$.

Effect of CPA. To establish whether NE evoked large STICs by releasing $\mathrm{Ca}^{2+}$ from intracellular stores, we examined the effects of the $\mathrm{Ca}^{2+}$-ATPase inhibitor CPA $(10 \mu \mathrm{M})$ on the response. Figure $3 A$ shows a typical experiment in which the response to repeated applications of NE was examined in the presence of CPA. Before application of CPA, NE evoked large inward currents that became progressively smaller in the presence of CPA. Figure $3 B$ shows a summary for

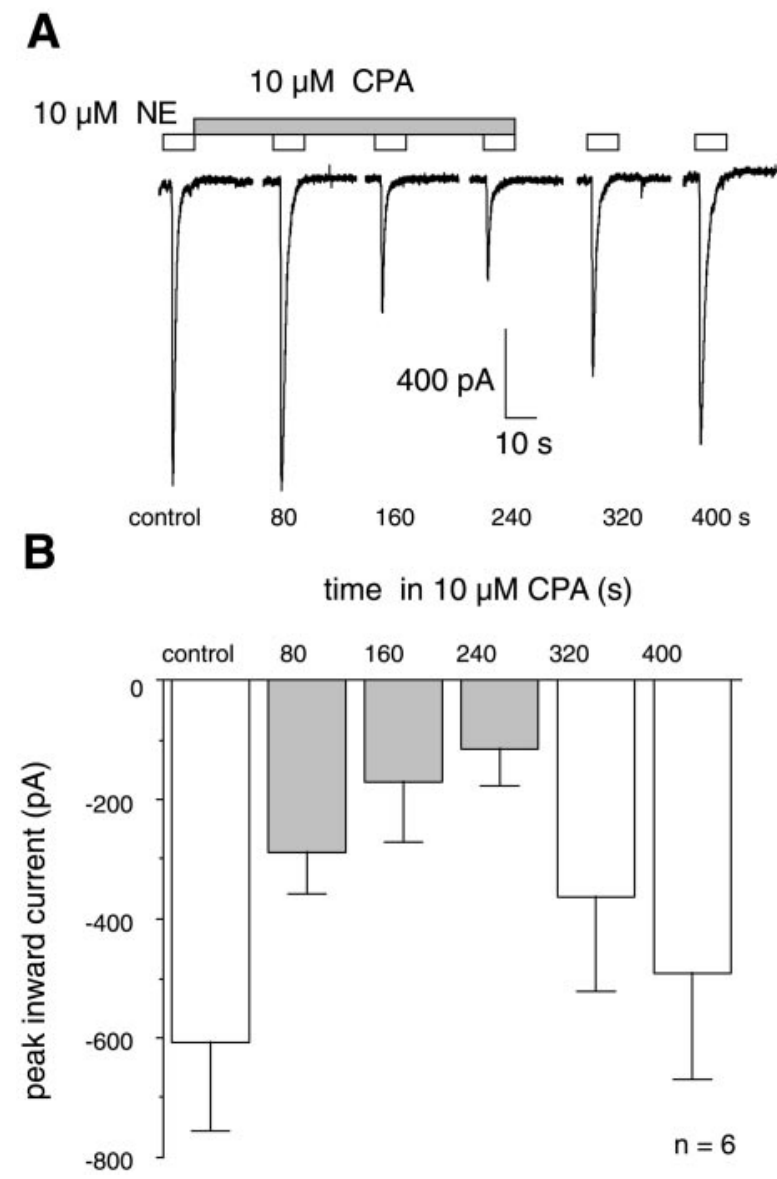

Fig. 3. Depletion of intracellular stores reduces the response to NE. $A$ : a typical experiment in which NE was applied to a cell before, during, and after application of $10 \mu \mathrm{M}$ cyclopiazonic acid (CPA). This resulted in a progressive decrease in the amplitude of the NE-evoked response, which returned toward control levels on removal of CPA. $B$ : a summary of 6 similar experiments in which CPA reversibly decreased the amplitude of the NE-evoked currents. six similar experiments in which the peak inward current was reduced from $-604 \pm 149 \mathrm{pA}$ to -116 $\mathrm{pA} \pm 63 \mathrm{pA}$ after $240 \mathrm{~s}$ in CPA $(P<0.05)$. Within $160 \mathrm{~s}$ of the removal of CPA, NE evoked large inward currents that were not significantly different from control $(-501 \pm 180 \mathrm{pA})$. These data support the idea that NE caused the release of $\mathrm{Ca}^{2+}$ from intracellular stores.

Inhibition of phospholipase $C$ with NCDC. Previously we demonstrated (21) that the inhibitor of inositol 1,4,5-trisphosphate $\left(\mathrm{IP}_{3}\right)$-dependent release, 2-APB, abolished the response to $\mathrm{NE}$ in urethral interstitial cells (28). More recent studies (23) have questioned the specificity of 2-APB and suggested that it may act by inhibiting store refilling rather than inhibiting store release. Therefore, we examined the effects of the phospholipase C inhibitor NCDC $(100 \mu \mathrm{M})$ on NE-evoked currents. Figure $4 A$ shows a typical experiment in which NE evoked large inward currents before the addition of NCDC. In its presence, spontaneous activity was abolished as reported previously (28), and the response to $\mathrm{NE}$ was inhibited (Fig. $4 B$ ). Figure $4 C$ shows a summary for six cells in which NE evoked mean inward currents that were $-396 \pm 97 \mathrm{pA}$ in amplitude before, compared with $-14 \pm 9 \mathrm{pA}$ after, application of NCDC $(P<0.05)$. To test directly for the possibility that NCDC blocked $\mathrm{Cl}^{-}$channels, we examined its effects on $\mathrm{Cl}^{-}$currents evoked by caffeine. Figure $4 D$ shows a typical experiment in which application of caffeine $(10 \mathrm{mM})$ to a cell held at $-60 \mathrm{mV}$ evoked a large inward current. In the presence of NCDC (100 $\mu$ M; Fig. $4 E)$, application of caffeine evoked a current of similar amplitude to control. Figure $4 F$ shows a summary of four experiments in which caffeine application evoked large inward currents of $-383 \pm 77 \mathrm{pA}$. In the presence of $100 \mu \mathrm{M}$ NCDC, the caffeine-evoked currents were slightly increased to $-439 \pm 67 \mathrm{pA}$, but this was not significant $(P=0.08)$. The above data suggest that the effects of NCDC are not mediated through blockade of $\mathrm{Cl}^{-}$channels and are consistent with our previous findings that the effects of $\mathrm{NE}$ are mediated by an $\mathrm{IP}_{3}$-dependent mechanism (28).

Involvement of $\mathrm{Ca}^{2+}$-activated $\mathrm{Cl}^{-}$channels. The data presented so far support the idea that activation of $\alpha_{1}$-adrenoceptors stimulates phospholipase C, leads to the production of $\mathrm{IP}_{3}$, and consequently releases $\mathrm{Ca}^{2+}$ from intracellular stores. This, in turn, activates $\mathrm{Ca}^{2+}$-sensitive channels on the cell membrane and elicits large transient inward currents. To test whether the NE-induced currents were carried by $\mathrm{Cl}^{-}$ions through $\mathrm{Ca}^{2+}$-activated $\mathrm{Cl}^{-}$channels previously characterized in these cells (27), we examined the reversal potential of the NE-induced current and the effects of different $\mathrm{Cl}^{-}$channel blockers on this current. Figure $5 A$ shows the effects of $\mathrm{NE}$ on a cell recorded with symmetrical $\mathrm{Cl}^{-}$solutions [chloride equilibrium potential $\left.\left(E_{\mathrm{Cl}}\right)=0 \mathrm{mV}\right]$ and held at a variety of voltages ranging from -60 to $+40 \mathrm{mV}$. When the cell was held at $-60 \mathrm{mV}$, NE application evoked inward currents that became progressively smaller in amplitude as the cell was depolarized toward $0 \mathrm{mV}$. At potentials positive to $0 \mathrm{mV}$, the currents were outward and increased 
A

Control

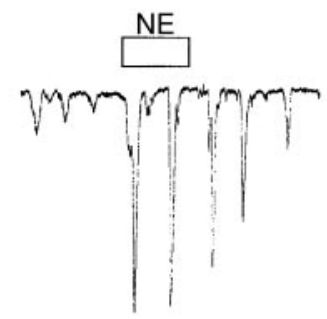

B

$N C D C$
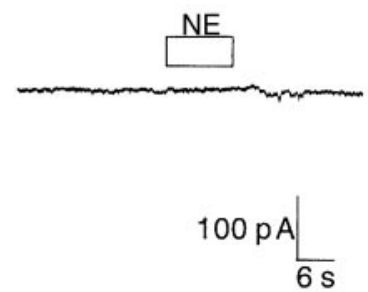

C

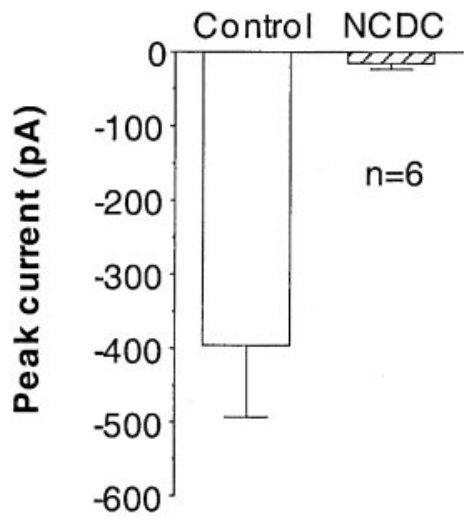

Control

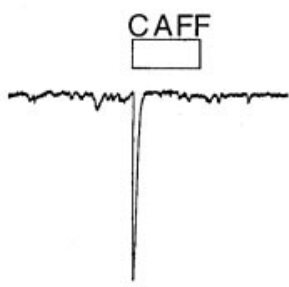

$\mathbf{E}$

$N C D C$

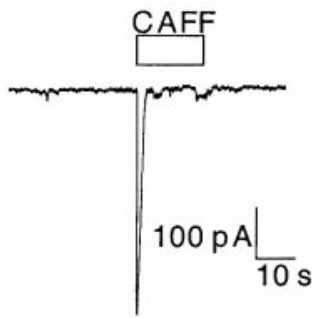

$\mathbf{F}$

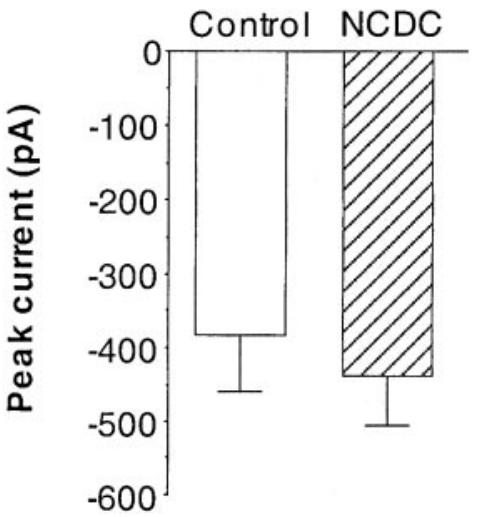

Fig. 4. Inhibition of phospholipase $\mathrm{C}$ abolishes the response to NE. A: effect of NE in the absence of 2-nitro4-carboxyphenyl- $N, N$-diphenylcarbamate (NCDC). B: inhibition of phospholipase $\mathrm{C}$ in the presence of NCDC $(100 \mu \mathrm{M})$ abolished both spontaneous activity and the response to NE. $C$ : a summary of 6 similar experiments in which NCDC depressed the amplitude of NE-evoked currents. $D$ and $E$ show the lack of effect of NCDC on caffeine (Caff)-evoked $\mathrm{Cl}^{-}$currents. $F$ : a summary of 4 similar experiments in which NCDC failed to block caffeine-evoked $\mathrm{Cl}^{-}$currents. in amplitude as the cell was held at more depolarized potentials. A summary of six similar experiments is shown in Fig. $5 B$ where the peak amplitude of the inward current was plotted at different holding potentials. Under these conditions, the NE-evoked current reversed close to $0 \mathrm{mV}$, suggesting that the current was carried by $\mathrm{Cl}^{-}$ions. In a separate set of experiments, we examined the effects altering the external $\mathrm{Cl}^{-}$concentration on the reversal potential of the NE-evoked current. A series of 400-ms voltage ramps from -50 to $+50 \mathrm{mV}$ were applied to cells every $500 \mathrm{~ms}$ before and during application of NE. Figure $5 C$ shows a typical experiment in which the NE-sensitive currents were obtained and plotted against voltage. Under control conditions $\left(E_{\mathrm{Cl}}=0 \mathrm{mV}\right)$, the NE-sensitive current reversed at $-1 \mathrm{mV}$, and when the external $\mathrm{Cl}^{-}$concentration was decreased to $49 \mathrm{mM}\left(E_{\mathrm{Cl}}=27 \mathrm{mV}\right)$, the reversal potential of the inward current shifted to 25 $\mathrm{mV}$. In four similar experiments, the reversal potential of the NE-sensitive currents shifted from $0 \pm 2 \mathrm{mV}$ to $23 \pm 2 \mathrm{mV}$ when external $\mathrm{Cl}^{-}$was reduced from 135 to
$49 \mathrm{mM}(P<0.01$, data corrected for junction potentials of $-3 \mathrm{mV}$ and $+2 \mathrm{mV}$ in normal and reduced external $\mathrm{Cl}^{-}$solutions, respectively).

The above data are consistent with idea that NEevoked currents are due to the stimulation of $\mathrm{Cl}^{-}$ currents. Further evidence to support this is presented in Fig. 6. In Fig. 6, $A$ and $C$, application of NE induced currents that were markedly reduced in the presence of either 9-AC $(1 \mathrm{mM})$ or niflumic acid (10 $\mu \mathrm{M})$, respectively. Figure $6 B$ shows a summary for six experiments in which 9-AC $(1 \mathrm{mM})$ significantly reduced the inward currents evoked by $\mathrm{NE}$ from $-1,253 \pm 510 \mathrm{pA}$ to $-299 \pm 89 \mathrm{pA}(P<0.05)$. Similarly, niflumic acid decreased the NE-evoked inward currents from $-813 \pm 185 \mathrm{pA}$ to $-140 \pm 26$ $\mathrm{pA}(P<0.05, n=6)$. After washout of both drugs, the response to $\mathrm{NE}$ returned and was not significantly different from control.

Tension recordings. Having characterized the effects of $\mathrm{NE}$ on isolated urethral interstitial cells, we next wanted to establish whether they played any role in 
Fig. 5. NE-evoked currents reverse close to $E_{\mathrm{Cl}} . A$ : a typical example of the effect of NE at a variety of holding potentials. $B$ : a summary of 6 similar NE-evoked currents were plotted at different holding potentials. C: NEsensitive currents recorded when external $\mathrm{Cl}^{-}$was shifted from 135 to 49 $\mathrm{mM}$. These currents reversed close to $E_{\mathrm{Cl}}$, suggesting that they were carried predominantly by $\mathrm{Cl}^{-}$ions. experiments in which the amplitude of

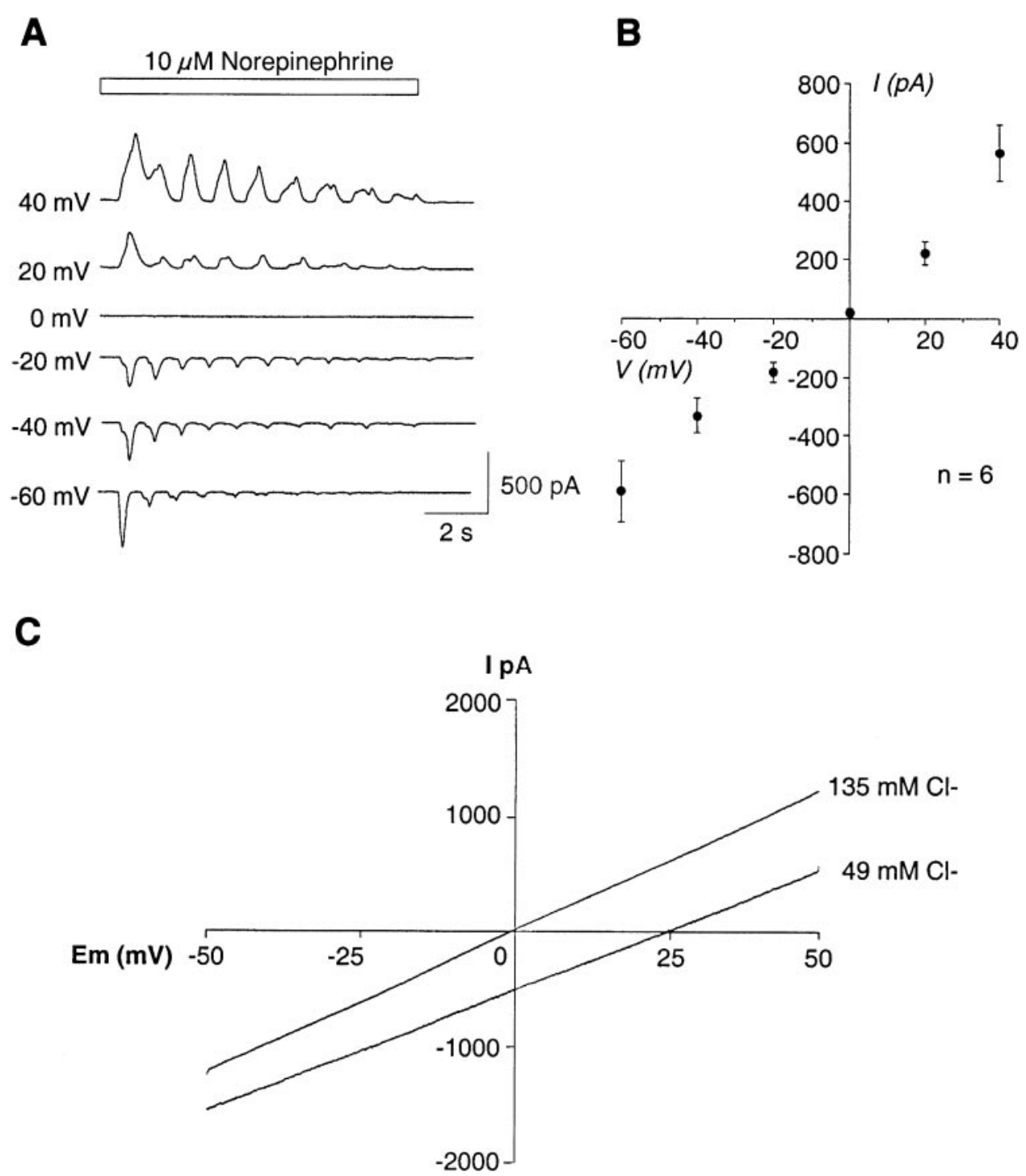

mediating noradrenergic neurotransmission. To test this possibility, the effect of transmural nerve stimulation was examined on strips of urethra in the presence of atropine $(1 \mu \mathrm{M})$ and $N^{\omega}$-nitro-L-arginine (10 $\mu \mathrm{M})$ to block the contribution of cholinergic and nonadrenergic noncholinergic (NANC) transmitters, respectively. Pulses $(0.3-\mathrm{ms}$ duration, $10 \mathrm{~Hz})$ were applied for $0.1,0.3,1,3$ and $10 \mathrm{~s}$. Figure $7, A$ and $C$, shows typical responses of a urethral strip to each stimulation. Increasing the duration of stimulation increased both the amplitude and duration of contraction. In the presence of phentolamine $(1 \mu \mathrm{M})$, the contractile responses to nerve stimulation were abolished, suggesting that only noradrenergic responses were evoked under these conditions ( $n=3$, data not shown). We next examined the effects of blocking $\mathrm{Cl}^{-}$channels on the response to nerve stimulation. Figure $7 A$ shows a typical experiment in which nerve evoked contractions were elicited in the absence and presence of niflumic acid $(100 \mu \mathrm{M})$. Because niflumic acid has been demonstrated to open large conductance $\mathrm{Ca}^{2+}$-activated $\mathrm{K}^{+}$
(BK) channels (11), all experiments were carried out in the presence of penitrem A $(100 \mu \mathrm{M})$ to block BK channels $(14,18)$. Application of niflumic acid reduced spontaneous contractions and decreased the amplitude of nerve-evoked contractions. The bar chart in Fig. 7B shows a summary of six similar experiments where the peak contraction amplitude was measured before and during application of niflumic acid. Data were normalized to the response obtained by a stimulation duration of $10 \mathrm{~s}$ in the absence of $\mathrm{Cl}^{-}$channel blockers. In the presence of niflumic acid, the amplitude of contraction was significantly reduced at $0.3,1$, and $10 \mathrm{~s}$ to $14 \pm 4$, $16 \pm 5$, and $18 \pm 4 \%$, respectively $(P<0.05)$. The effects of 9-AC (1 mM) were also examined on neurogenic contractions. Figure $7 C$ shows a typical response to nerve stimulation before and during application of 9-AC. Note again that both spontaneous and neurogenic contractions were depressed in the presence of 9-AC. Figure $7 D$ shows summary data for seven similar experiments in which 9-AC reduced the amplitude of contraction in response to $0.3-, 1-$, and 10 -s stimula- 
A

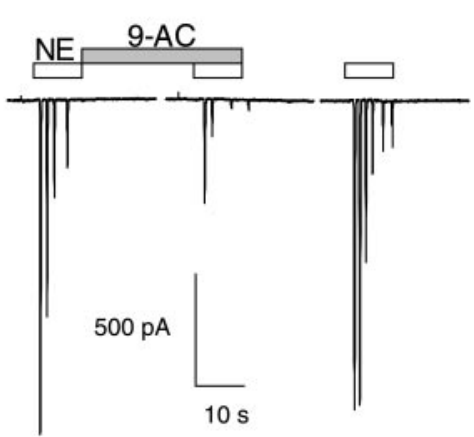

B

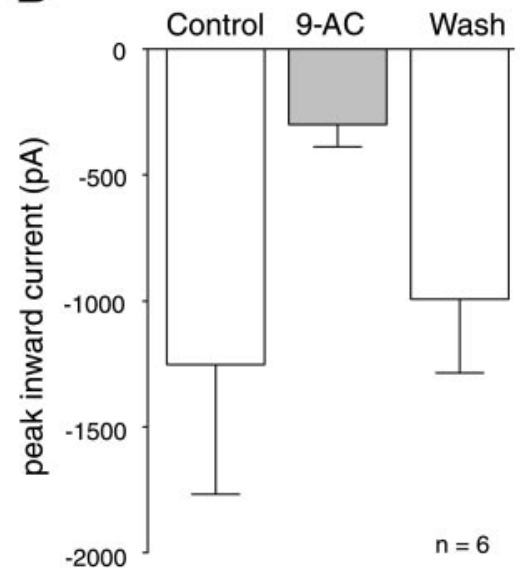

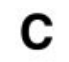
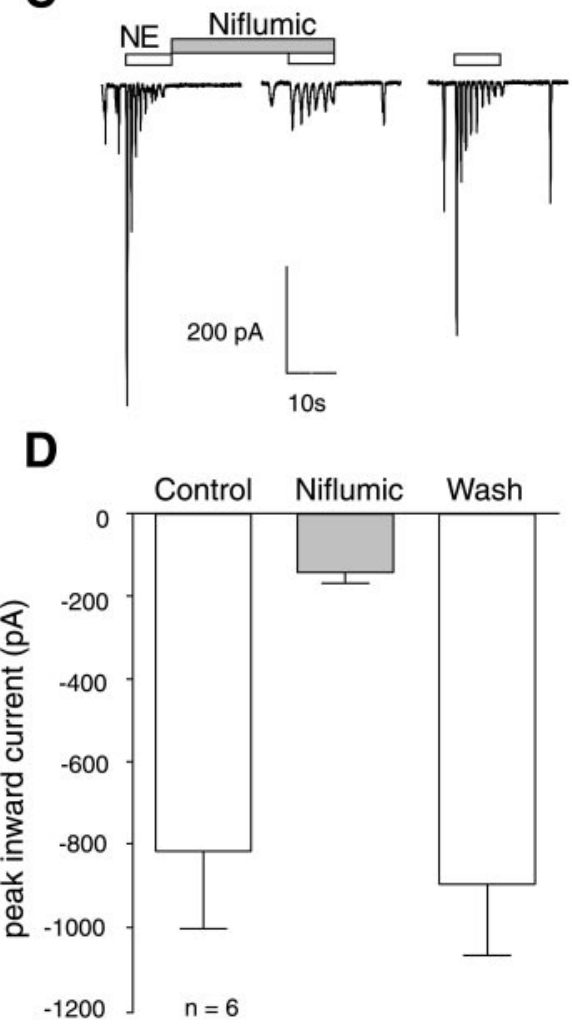

Fig. 6. $\mathrm{Cl}^{-}$channel blockers reduce the response to NE. $A$ and $C$ show the effect of NE before, during, and after application of 9-anthracenecarboxylic acid (9-AC; $1 \mathrm{mM}$ ) and niflumic acid $(10 \mu \mathrm{M})$, respectively. $B$ : a summary of 6 experiments in which 9-AC reversibly reduced the amplitude of the NE-evoked inward current. $D$ : a summary of 6 experiments in which the effect of niflumic acid on NE-evoked currents was examined. tion periods to $16 \pm 4,16 \pm 3$, and $30 \pm 5 \%$, respectively $(P<0.05)$.

\section{DISCUSSION}

A variety of studies have demonstrated that ICC play a central role in the initiation, coordination, and modulation of spontaneous activity in the GI tract (25, 26, 31). Cells with characteristics similar to the ICC in the gut have recently been isolated in a variety of tissues from the lower urinary tract $(22,27,28)$. Although their function in these tissues has not been thoroughly established, we have hypothesized that urethral interstitial cells contribute to the generation of tone by acting as pacemakers to "drive" the surrounding smooth muscle (27). Two main pieces of evidence support this contention. First, isolated interstitial cells fire regular spontaneous slow waves, which resemble the electrical activity recorded in whole tissues with microelectrodes, whereas smooth muscle cells are electrically quiescent $(12,13,27)$. Second, the slow waves recorded in whole tissues and isolated interstitial cells are abolished when $\mathrm{Ca}^{2+}$ release from $\mathrm{IP}_{3}$-sensitive stores is inhibited or $\mathrm{Ca}^{2+}$-activated $\mathrm{Cl}^{-}$ channels are blocked $(12,27,28)$

Modulation of this mechanism by excitatory neurotransmitters such as NE could provide an efficient means to alter tone, because an increase in slow wave frequency could lead to an enhancement of contractile force. Previous studies have demonstrated that NE is the major excitatory transmitter in the urethra $(2,3)$, and for this reason we examined the mechanisms of its action on rabbit urethral interstitial cells. Hashitani et al. (12) demonstrated that NE increases the frequency of STDs in the rabbit urethra by enhancing the oscillatory release of $\mathrm{Ca}^{2+}$ from intracellular stores, which results in the periodic activation of $\mathrm{Cl}^{-}$channels. Because urethral smooth muscle cells in the rabbit possess little $\mathrm{Ca}^{2+}$-activated $\mathrm{Cl}^{-}$current (27), it is unlikely that the observed changes in electrical activity recorded with intracellular microelectrodes reflect an action on these cells and leaves the intriguing possibility that interstitial cells act as the primary target for neuronally released NE.

In a previous study (27), we demonstrated that under current-clamp conditions, NE produced responses in isolated interstitial cells that appear to be remarkably similar to those recorded in whole tissue preparations with sharp microelectrodes (12). Thus NE produced an initial large slow wave that was followed by a series of more frequent but shorter slow waves. The reason for such a pattern of activity became apparent when cells were held under voltage clamp, where NE typically induced a large inward current that was followed by more frequent, gradually diminishing inward currents. A number of lines of evidence suggest that the NE-evoked currents reflected the stimulation of $\mathrm{Ca}^{2+}$-activated $\mathrm{Cl}^{-}$currents that have been demonstrated in a variety of smooth muscles $(1,20)$. First, when cells were held under voltage clamp, the currents reversed close to $E_{\mathrm{Cl}}$ in symmetrical $\mathrm{Cl}^{-}$solutions and shifted in a predictable manner when $E_{\mathrm{Cl}}$ was altered. Second, they were significantly decreased by either 
A

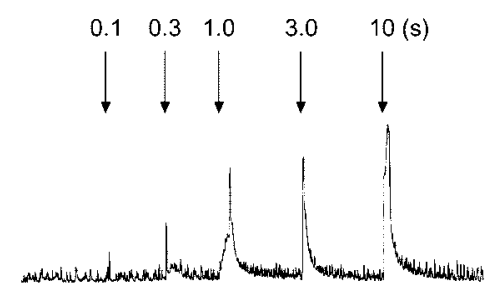

Fig. 7. Neurogenic contractions are attenuated in the presence of $\mathrm{Cl}^{-}$channel blockers. A: effect of field stimulation on tension in a strip of rabbit urethra. Pulses [0.3-ms duration, $50 \mathrm{~V}$ (nominal), $10 \mathrm{~Hz}$ ] were applied for 0.1 , $0.3,1,3$, and $10 \mathrm{~s}$. In the presence of $100 \mu \mathrm{M}$ niflumic acid (bottom). B: a summary bar chart for 6 experiments in which the amplitude of contraction at each stimulation frequency was plotted in the absence (control) and presence of niflumic acid. $C$ : a typical example of the effect of nerve stimulation before (top) and during (bottom) application of 9-AC $(1 \mathrm{mM})$. $D$ : a summary of 6 similar experiments.

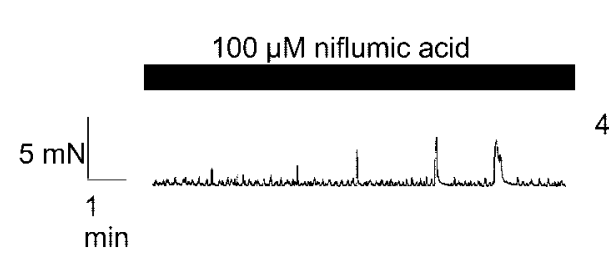

B

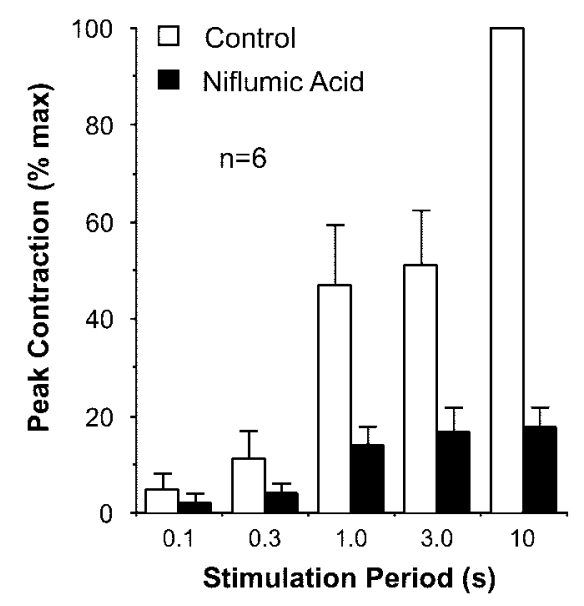

C
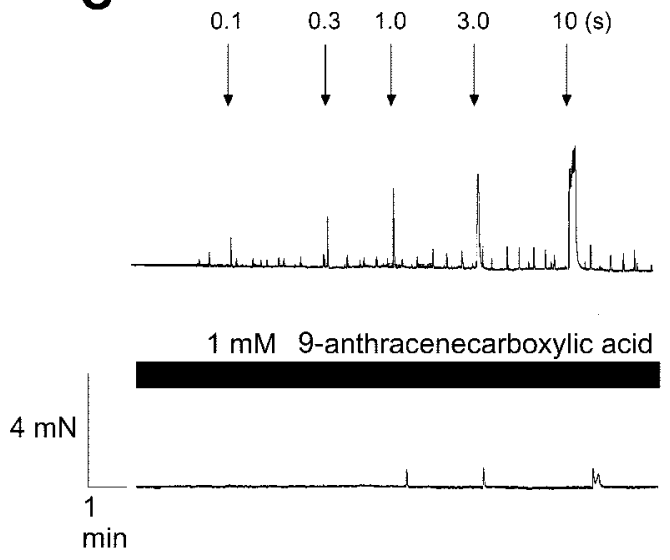

D

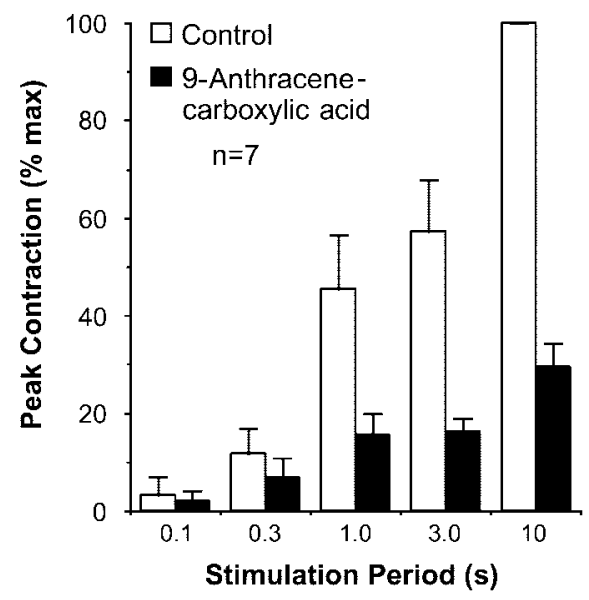

niflumic acid or 9-AC. Although the concentration of 9-AC (1 mM) used to block the response is relatively high compared with other tissues (20), we have previously demonstrated that this concentration selectively blocks the $\mathrm{Cl}^{-}$current in urethral interstitial cells (27).

When we examined the pharmacology of the $\mathrm{NE}$ response, it appeared to be similar to the pathway described in a number of smooth muscles $(1,4,5,30)$. Thus the response to NE was abolished by either phentolamine or prazosin, suggesting that it was mediated via activation of $\alpha_{1}$-adrenoceptors. Similarly, its effects were attenuated when phospholipase $\mathrm{C}$ was blocked with NCDC, which is consistent with our previous observation that the $\mathrm{IP}_{3}$ inhibitor 2-APB (21) inhibits $\mathrm{NE}$ responses in urethral interstitial cells (28). These data support the idea that NE mediates its effects by upregulating the normal pacemaking mechanism in these cells.

In recent years, a number of studies have demonstrated that ICC in the gut act as important intermediaries in both excitatory and inhibitory neurotransmission $(8,26,34,35)$. The evidence to support this role in the gut has been obtained by using a variety of techniques including gene knockout technology. Perhaps the most convincing demonstration that ICC play a central role in neurotransmission in the gut has been obtained from mutant mice $\left(\mathrm{W} / \mathrm{W}^{\mathrm{v}}\right)$ that failed to develop intramuscular ICC. In these animals, both excitatory and inhibitory nerve evoked responses were greatly attenuated $(8,34,35)$. Unfortunately, similar rabbit knockouts are presently unavailable. However, we have previously demonstrated that in marked contrast to the smooth muscle cells, interstitial cells in the urethra possess abundant $\mathrm{Ca}^{2+}$-activated $\mathrm{Cl}^{-}$current (27). We exploited this difference in the present study to assess the contribution of interstitial cells to noradrenergic neurotransmission in strips of urethra by attempting to pharmacologically knock out interstitial cells using $\mathrm{Cl}^{-}$channel blockers. Although this method lacked the elegance of genetic knockout technologies, it produced effects that were consistent with abolishing the contribution of interstitial cells. Thus, in the presence of either niflumic or 9-AC, both spontaneous and neurogenic contractions were attenuated. These data tentatively suggest that interstitial cells in the urethra not only contribute to spontaneous mechanical activity but also may play an important role in neurotransmission.

Although the idea that interstitial cells mediate neurotransmission in the urethra may be appealing, the results obtained on whole tissue strips should be interpreted with caution. This preparation consists of a 
complex arrangement of nerves, smooth muscle, and interstitial cells, all of which may be affected by the $\mathrm{Cl}^{-}$channel blockers. The observed effects on neurogenic contractions may be caused by a presynaptic action of the $\mathrm{Cl}^{-}$channel blockers, which could inhibit neurotransmitter output. However, inhibition of neuronal $\mathrm{Cl}^{-}$channels should prolong neuronal action potentials and, consequently, enhance neurotransmitter output. Alternatively, the $\mathrm{Cl}^{-}$channel blockers could inhibit neurotransmitter output by blocking neuronal $\mathrm{Ca}^{2+}$ channels. Although we cannot rule out this possibility, it is interesting to note that Jackson et al. (16) have failed to demonstrate any effect of niflumic acid on action potential-evoked axonal $\mathrm{Ca}^{2+}$ transients in the rat vas deferens, suggesting that $\mathrm{Ca}^{2+}$ influx is unaffected by niflumic acid.

Recent immunohistochemical evidence presented by Smet et al. (29) and Waldeck et al. (33) would also support our contention that urethral interstitial cells play a role in neurotransmission. These studies demonstrated the presence of branched interstitial cells in the human, guinea pig, and rabbit urethras, respectively, that were immunopositive for cGMP and support the idea that they may be important in mediating neurally released nitric oxide responses. Unfortunately, the detailed immunohistochemistry and electronmicroscopy data that have been provided to support the role of ICC as mediators of neurotransmission in the gut provided are not yet available in the urethra. Future studies should focus on the relationships among nerves, interstitial cells, and the surrounding smooth muscle in the urethra to determine whether the interstitial cells are selectively innervated.

We thank Action Research and the Wellcome Trust for funding this study.

\section{REFERENCES}

1. Amedee T, Large WA, and Wang Q. Characteristics of chloride currents activated by noradrenaline in rabbit ear artery cells. J Physiol 428: 501-16, 1990.

2. Andersson KE. Pharmacology of lower urinary tract smooth muscles and penile erectile tissues. Pharmacol Rev 45: 253-307, 1993.

3. Andersson KE and Sjögren C. Aspects on the physiology and pharmacology of the bladder and urethra. Prog Neurobiol 19: 71-89, 1982.

4. Berridge MJ. Inositol trisphosphate and calcium signalling. Nature 361: 315-323, 1993.

5. Boittin F, Macrez N, Halet G, and Mironneau J. Norepinephrine-induced $\mathrm{Ca}^{2+}$ waves depend on $\mathrm{InsP}_{3}$ and ryanodine receptor activation in vascular myocytes. Am J Physiol Cell Physiol 277: C139-C151, 1999.

6. Brading AF, McCoy R, and Dass N. $\alpha_{1}$-Adrenoceptors in urethral function. Eur Urol 36: 74-79, 1999.

7. Bridgewater M, MacNeil HF, and Brading AF. Regulation of tone in pig urethral smooth muscle. J Urol 150: 223-228, 1993.

8. Burns AJ, Lomax AEJ, Torihashi S, Sanders KM, and Ward SM. Interstitial cells of Cajal mediate inhibitory neurotransmission in the stomach. Proc Natl Acad Sci USA 93: 1200812013, 1996.

9. Callahan SM and Creed KE. The effects of oestrogens on spontaneous activity and responses to phenylephrine of the mammalian urethra. J Physiol 358: 35-46, 1985.
10. Cotton KD, Hollywood MA, McHale NG, and Thornbury KD. $\mathrm{Ca}^{2+}$ current and $\mathrm{Ca}^{2+}$-activated chloride current in isolated smooth muscle cells of the sheep urethra. J Physiol 505: 121-131, 1997.

11. Greenwood IA and Large WA. Comparison of the effects of fenamates on Ca-activated chloride and potassium currents in rabbit portal vein smooth muscle cells. $B r J$ Pharmacol 116: 2939-2948, 1995.

12. Hashitani H, Van Helden DF, and Suzuki H. Properties of spontaneous depolarizations in circular smooth muscle cells of rabbit urethra. Br J Pharmacol 118: 1627-1632, 1996.

13. Hashitani $\mathbf{H}$ and Edwards FR. Spontaneous and neurally activated depolarizations in smooth muscle cells of the guinea pig urethra. J Physiol 514: 459-470, 1999.

14. Hollywood MA, McCloskey KD, McHale NG, and Thornbury KD. Characterization of the outward $\mathrm{K}^{+}$currents in isolated smooth muscle cells from the sheep urethra. Am J Physiol Cell Physiol 279: C420-C428, 2000.

15. Horn $\mathbf{R}$ and Marty A. Muscarinic activation of ionic currents measured by a new whole-cell recording method. J Gen Physiol 92: 145-159, 1988.

16. Jackson MV, Trout SJ, Brain KL, and Cunnane TC. Characterization of action potential-evoked calcium transients in mouse postganglionic sympathetic axon bundles. J Physiol 537: $3-16,2001$

17. Komuro T, Tokui K, and Zhou DS. Identification of the interstitial cells of Cajal. Histol Histopathol 11: 769-786, 1996.

18. Knaus HG, McManus OB, Lee SH, Schmalhofer WA, Garcia-Calvo M, Helms LMH, Sanchez M, Giangiacomo K, Reuben JP, Smith AB, Kaczorowski GJ, and Garcia ML. Tremorgenic indole alkaloids potently inhibit smooth muscle high-conductance calcium-activated potassium channels. Biochemistry 33: 5819-5828, 1994.

19. Langton P, Ward SM, Carl A, Norell MA, and Sanders KM. Spontaneous electrical activity of interstitial cells of Cajal isolated from canine proximal colon. Proc Natl Acad Sci USA 86: 7280-7284, 1989.

20. Large WA and Wang Q. Characteristics and physiological role of the $\mathrm{Ca}^{2+}$-activated $\mathrm{Cl}^{-}$conductance in smooth muscle. Am J Physiol Cell Physiol 271: C435-C454, 1996.

21. Maruyama T, Kanaji T, Nakade S, Kanno T, and Mikoshiba K. 2APB, 2-Aminoethoxydiphenyl borate, a membranepenetrable modulator of $\operatorname{Ins}(1,4,5) \mathrm{P}_{3}$-induced $\mathrm{Ca}^{2+}$ release. J Biochem (Tokyo) 122: 498-505, 1997.

22. McCloskey KD and Gurney AM. cKit-positive cells in the guinea pig bladder. J Physiol 536: 95, 2001.

23. Prakriya M and Lewis RS. Potentiation and inhibition of $\mathrm{Ca}^{2+}$ release-activated $\mathrm{Ca}^{2+}$ channels by 2-aminoethyldiphenylborate (2-APB) occurs independently of $\mathrm{IP}_{3}$ receptors. $J$ Physiol 536: 3-19, 2001.

24. Rae J, Cooper K, Gates P, and Watsky M. Low access resistance perforated patch recordings using amphotericin B. J Neurosci Methods 37: 15-26, 1991.

25. Rumessen JJ and Thuneberg L. Pacemaker cells in the gastrointestinal tract: interstitial cells of Cajal. Scand J Gastroenterol 31: 82-94, 1996.

26. Sanders KM. A case for interstitial cells of Cajal as pacemakers and mediators of neurotransmission in the gastrointestinal tract. Gastroenterology 111: 492-515. 1996.

27. Sergeant GP, Hollywood MA, McCloskey KD, Thornbury KD, and McHale NG. Specialised pacemaking cells in the rabbit urethra. J Physiol 526: 359-366, 2000.

28. Sergeant GP, Hollywood MA, McCloskey KD, McHale NG, and Thornbury KD. Role of $\mathrm{IP}_{3}$ in modulation of spontaneous activity in pacemaker cells of rabbit urethra. Am J Physiol Cell Physiol 280: C1349-C1356, 2001.

29. Smet PJ, Jonavicius J, Marshall VR, and De Vente J. Distribution of nitric oxide synthase-immunoreactive nerves and identification of the cellular targets of nitric oxide in guinea pig and human urinary bladder by cGMP immunohistochemistry. Neuroscience 71: 337-348, 1996. 
30. Somlyo AV, Bond M, Somlyo AP, and Scarpa A. Inositol trisphosphate-induced calcium release and contraction in vascular smooth muscle. Proc Natl Acad Sci USA 82: 5231-5235, 1985.

31. Thuneberg L, Rumessen \& Mikkelsen HB JJ. The interstitial cells of Cajal: intestinal pacemaker cells? In: Motility of the Digestive Tract, edited by Wienback M. New York: Raven, 1982, p. $115-122$.

32. Torihashi S, Gerthoffer WT, Kobayashi S, and Sanders KM. Identification and classification of the interstitial cells in the canine proximal colon by ultrastructure and immunocytochemistry. Histochemistry 101: 169-183, 1994.
33. Waldeck K, Ny L, Persson K, and Andersson KE. Mediators and mechanisms of relaxation in rabbit urethral smooth muscle. Br J Pharmacol 123: 617-624, 1998.

34. Ward SM, Beckett EAH, Wang XY, Baker F, Khoyi M, and Sanders KM. Interstitial cells of Cajal mediate cholinergic neurotransmission from enteric motor neurons. J Neurosci 20: 1393-1403, 2000.

35. Ward SM, Morris G, Reese L, Wang XY, and Sanders KM. Interstitial cells of Cajal mediate enteric inhibitory neurotransmission in the lower esophageal and pyloric sphincters. Gastroenterology 115: 314-329, 1998.

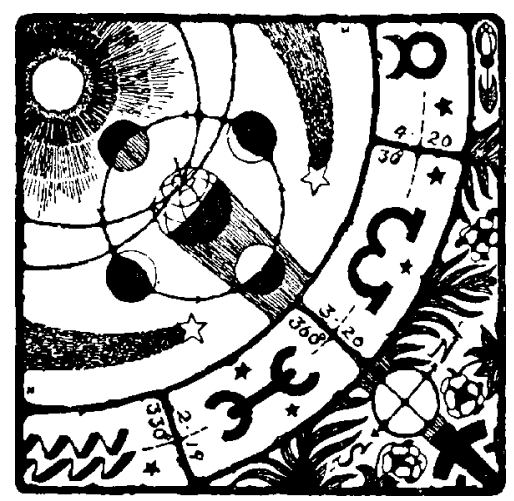

